\title{
Geodynamic processes in the Andes of Central Chile and Argentina: an introduction
}

\author{
SERGIO A. SEPÚLVEDA ${ }^{1 *}$, LAURA B. GIAMBIAGI ${ }^{2}$, STELLA M. MOREIRAS $^{2}$, \\ LUISA PINTO $^{1}$, MAISA TUNIK ${ }^{3}$, GREGORY D. HOKE ${ }^{4} \&$ MARCELO FARÍAS ${ }^{1}$ \\ ${ }^{1}$ Departamento de Geología, Universidad de Chile, Plaza Ercilla 803, Santiago, Chile \\ ${ }^{2}$ IANIGLA-CCT Mendoza-CONICET, Av. Ruiz Leal s/n, Parque \\ Gral San Martin (5500) Mendoza, Argentina \\ ${ }^{3}$ Universidad Nacional de Rio Negro, Av. Roca 1242, \\ (8332) Roca, Río Negro, Argentina \\ ${ }^{4}$ Department of Earth Sciences, Syracuse University, Syracuse, NY, USA \\ *Corresponding author (e-mail: sesepulv@ing.uchile.cl)
}

\begin{abstract}
The Andes, the world's largest non-collisional orogen, is considered the paradigm for geodynamic processes associated with the subduction of an oceanic plate below a continental plate margin. In the framework of UNESCO-sponsored IGCP 586-Y project, this Special Publication includes state-of-the-art reviews and original articles from a range of Earth Science disciplines that investigate the complex interactions of tectonics and surface processes in the subductionrelated orogen of the Andes of central Chile and Argentina (c. 27-39 ${ }^{\circ}$ S). This introduction provides the geological context of the transition from flat slab to normal subduction angles, where this volume is focused, along with a brief description of the individual contributions ranging from internal geodynamics and tectonics, Quaternary tectonics and related geohazards, to landscape evolution of this particular segment of the Andes.
\end{abstract}

Convergent continental margins are one of the firstorder expressions of the movement of Earth's tectonic plates atop a convecting mantle. The topography of convergent margins is due to the interactions of rock uplift, climate and surface processes that are dominantly driven by upper crustal and internal lithospheric deformation as well as erosional processes (e.g. Molnar \& Lyon-Caen 1988; Beaumont et al. 2004; Whipple \& Meade 2006). The Andes of central Chile and Argentina (c. 32-36 S, Figs 1 \& 2) straddle a potentially important transition in geodynamic boundary conditions imposed on the upper plate: a drastic change in the geometry of the subducting Nazca plate from 'flat' to normal subduction angles, from $c .5-10^{\circ}$ to $30^{\circ}$ (Cahill \& Isacks 1992; Fig. 1). This segment of the Andes is therefore a particularly suitable setting to evaluate the interplay between constructive deep mechanisms, resulting in rock uplift and lateral expansion of the Andes, and the mechanisms of exhumation and erosion that shape the landscape in an active, convergent margin.

The Central Andes are composed of different morphostructural units (from west to east; Figs 1 \& 2): the Chilean Coastal Cordillera, the Principal Cordillera (spanning Chile and Argentina), the Frontal Cordillera, the Argentine Precordillera and the Pampean Ranges (Jordan et al. 1983). Although previous studies attempt to constrain the magnitudes of orogenic shortening for each morphostructural unit, limited amounts of geochronology complicate attempts to constrain more tightly the rates of shortening and topographic uplift. There are several outstanding questions regarding the interplay between deep and surface processes in the development of the Andean Orogen over different timescales, as follows.

- What is the nature of the interaction between tectonic and surface processes in this sector of the Andes? In particular, are surface and tectonic processes part of a strongly coupled system?

- What control does the geometry of the subducting slab exert over the timing and style of deformation in the South American plate?

- How do deformation and denudation evolve in space and time? Are there differences between the flat slab $\left(32-33^{\circ} \mathrm{S}\right)$, the transitional (33$\left.34^{\circ} \mathrm{S}\right)$ and normal $\left(34-36^{\circ} \mathrm{S}\right)$ segments in this respect?

- What role do pre-existing crustal and lithospheric heterogeneities play in the development of the orogen? In particular, is there a link between heterogeneities in the overriding plate and the geometry of the subducting plate (flat v. normal subduction)? 


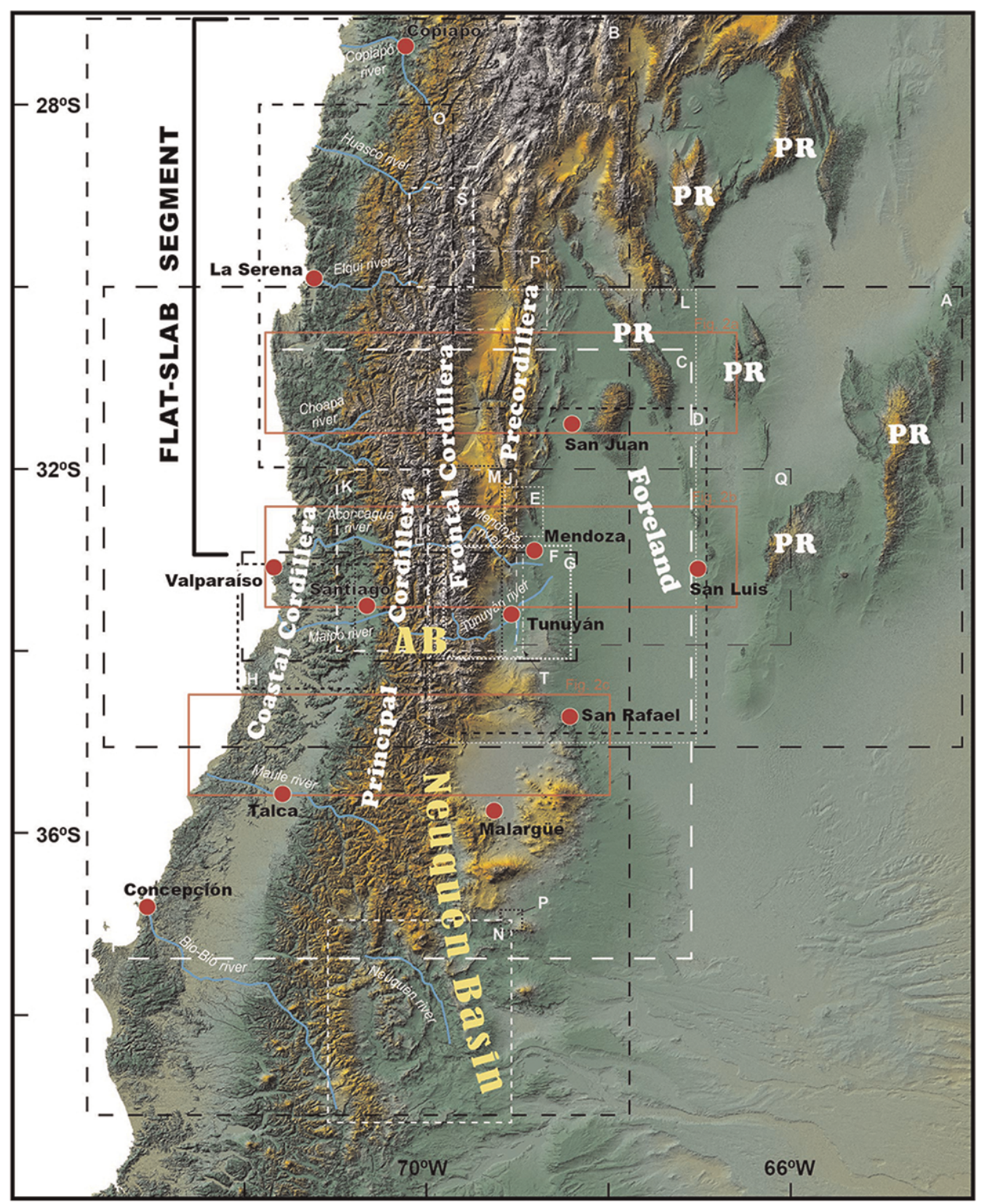

Fig. 1. Digital elevation model of the region showing morphologic zones, principal localities and rivers mentioned in this Special Publication. Study areas are indicated by boxes in segmented lines: A, Alvarez et al.; B, Carretier et al.; C, Charrier et al.; D, Cortés et al.; E, Costa et al.: F, García et al.; G, Giambiagi et al.; H, Godoy; I, Hermanns et al.; J, Hoke et al.; K, Jara et al.; L, Moreiras \& Páez; M, Moreiras \& Sepúlveda; N, Nainpauer et al.; O, Rodríguez et al.; P, Sagripanti et al.; Q, Sánchez et al.; R, Suriano et al.; S, Winocur et al.; T, Zárate et al. The position of the flat-slab segment (Cahill \& Isacks 1992) is represented. Red boxes mark the position of the $1^{\circ}$-wide swath topographic profiles shown in Figure 2. Abbreviations: AB, Abanico Basin; PR, Pampean Range. 


\section{INTRODUCTION}

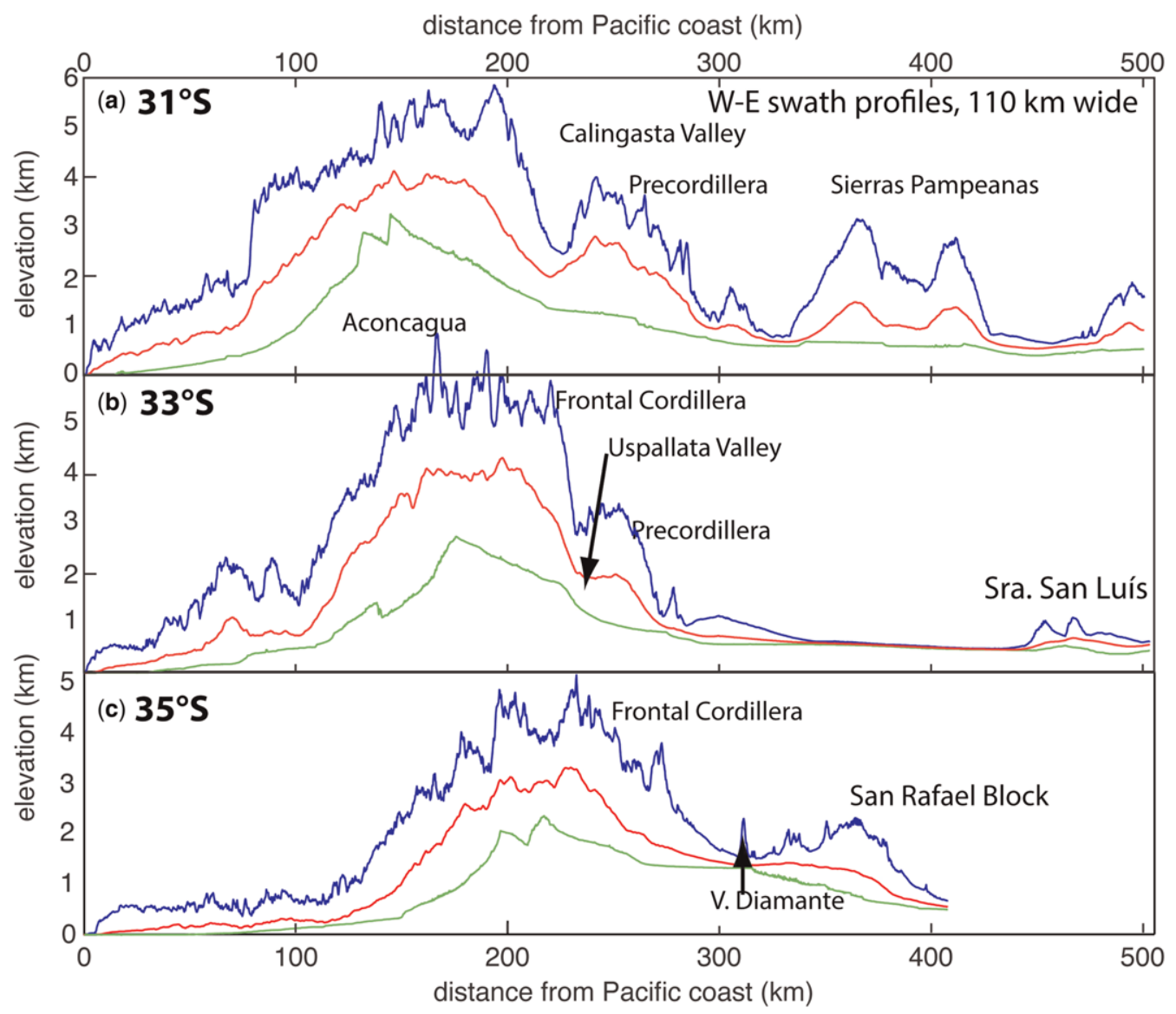

Fig. 2. Topographic profiles at $31^{\circ} \mathrm{S}(\mathbf{a}), 33^{\circ} \mathrm{S}(\mathbf{b})$ and $35^{\circ} \mathrm{S}(\mathbf{c})$ showing the maximum (blue), minimum (green) and mean (red) elevations constructed using a $250 \mathrm{~m}$ resolution resampling of the SRTM $90 \mathrm{~m}$ digital elevations model available from http://www.cgiar-csi.org/. Major topographic features are labelled on the swath profiles for reference. Location of swath profiles is indicated in Fig. 1.

- What role do mega-landslides play in shaping the landscape and erosion rates, and how do they relate to active tectonics, climate and river incision?

- How do Andean sedimentary basins evolve in relation to spatial and temporal variations in deformation and topographic uplift during the Miocene to present?

In the framework of UNESCO-sponsored IGCP 586-Y project 'The tectonics and geomorphology of the Andes $\left(32-34^{\circ} \mathrm{S}\right)$ : Interplay between shortterm and long-term processes', this collection of state-of-the-art reviews and original articles investigates the complex interactions between tectonics and surface processes in the non-collisional Andean Orogen of central Chile and Argentina (c. 27-39 $\left.{ }^{\circ} \mathrm{S}\right)$ with a particular emphasis on the area between $32^{\circ} \mathrm{S}$ and $34^{\circ} \mathrm{S}$.

\section{Internal geodynamics and tectonic evolution}

The Andes are considered the geodynamic archetype of a convergent, non-collisional mountain range and are generated by subduction of the oceanic lithosphere of the Nazca Plate beneath the continental lithosphere of the South American Plate. Consequently, the present-day architecture of the Andes Mountains is largely the result of convergence between the Pacific-Nazca and South American plates. However, these mountains preserve evidence of previous periods of contractional, extensional and strike-slip deformation along the proto-Pacific margin of southern Gondwana. The tectonic style of the different morphostructural units comprising the orogen is strongly influenced by pre-Andean structures, especially those developed 


\section{S. A. SEPÚLVEDA ET $A L$.}

during the Late Devonian-early Carboniferous Chanic Orogeny and the late Carboniferous-early Permian San Rafael Orogeny of the Gondwanan orogenic cycle (Ramos 1988; Mpodozis \& Ramos 1989; Giambiagi et al. 2011, 2014a; Heredia et al. 2012). The first chapter by Charrier et al. (2014) presents a review of the major geological features and tectonic events that occurred in the Andean region between $31^{\circ} \mathrm{S}$ and $37^{\circ} \mathrm{S}$ since early Phanerozoic time and prior to the Neogene Andean deformation. The authors synthesize current knowledge of pre-Andean orogenic cycles, as well as the influence of these cycles over Andean Orogeny since Neogene time, while emphasizing the importance of the relationship between magmatism, metamorphism, sedimentation and deformation.

Although the Andes have been described as a consequence of crustal shortening that leads to crustal thickening and surface uplift (Isacks 1988; Sheffels 1990; Allmendinger et al. 1997), the mechanisms by which this crustal shortening is achieved remain controversial. Giambiagi et al. (2014b) propose an integrated kinematic-mechanical model of the Maipo-Tunuyán transect $\left(33^{\circ} 40^{\prime} \mathrm{S}\right)$ across the Andes, describing the relation between horizontal shortening, surface uplift, crustal thickening and activity of the magmatic arc, while accounting for the main deep crustal processes that have shaped the Andes since early Miocene time.

During Eocene-early Miocene time, a protracted extensional event took place with deformation concentrated in the western sector of the Principal Cordillera, with the opening of the Abanico extensional basin (Charrier et al. 2002; Muñoz-Sáez et al. 2014). This event has been linked to a segmented rollback-subduction event (Mpodozis \& Cornejo 2012). Jara et al. (2014) study the role of width variation in the Eocene-lower Miocene Abanico Basin (Fig. 1) on the development of inverted structures in the Andes between 32 and $33^{\circ} \mathrm{S}$. They use analogue modelling to propose that the basin aperture increased southwards and was subsequently inverted by homogeneous shortening.

During this extensional regime, Oligocenelower Miocene retro-arc volcanism developed in the El Indio Belt. Winocur et al. (2014) shed light on the age and evolution of this belt where major mining districts are located, based on extensive fieldwork as well as geochronological and geochemical data. After many years of walking and studying the Andes, Godoy (2014) remarks on the along-strike lithological variations of the Neuquén Basin (Fig. 1) during Kimmeridgian-Hauterivian time. He recognizes thick Hauterivian andesitic flows in the high Cordillera and proposes that a volcanic event could be responsible for the isolation of the Neuquén Basin during Aptian-Albian time, despite a worldwide sea-level highstand.
South America, and especially the Andean region, are generally characterized by a lack of gravity data necessary to describe the crust's internal structure. Sánchez et al. (2014) geophysically characterize the upper crust of the Andean back-arc between 32 and $34^{\circ} \mathrm{S}$. Their gravimetric studies allow them to highlight and delineate two NWtrending features in the upper crust: (1) the San Pedro Ridge and the Tunuyán lineament; and (2) a lateral density contrast between the basement of the Western Sierras Pampeanas and that of the Precordillera, which they interpret as the geophysical expression of the contact between the Cuyania and Pampia terrains. Alvarez et al. (2014) present a new interpretation of Andean crustal structure between 32 and $34^{\circ} \mathrm{S}$ from GOCE satellite gravity data. In addition, they discuss the use of global gravity models to study the crustal structure at a regional scale.

Late Cenozoic compressional deformation led to development of an extensive retro-arc thrust-belt/ foreland basin system (Jordan et al. 1983; Ramos et al. 1996). Knowing the temporal-spatial pattern of Neogene orogenic exhumation and its relation to structural deformation, topographic evolution, basin development and sediment dispersal patterns in the southern Central Andes is crucial to reconstruct the geodynamic processes that controlled the building and erosion of the orogen. Suriano et al. (2014) analyse two Quaternary and OligoceneMiocene piggyback basins along the Precordillera at $30^{\circ} \mathrm{S}$; the first is controlled by climatic changes, and the second is related to tectonic activity in the Precordillera fold-thrust belt (Fig. 1). The authors postulate that understanding the dynamics of sediment accumulation in piggyback basins and the controlling allocyclic changes is essential to understand the geodynamics of an evolving orogen.

Sagripanti et al. (2014) explain the presence of Lower Cretaceous marine sedimentary deposits in the foreland of the Neuquén Basin. These deformed deposits are $70 \mathrm{~km}$ from the Andean orogenic front and $2 \mathrm{~km}$ above sea level due to local uplift on highangle basement reverse faults that reactivated a previous early Mesozoic rift system. The authors postulate that the increase in compression could be related to the decrease in the subduction angle and the expansion of the magmatic arc during the late Miocene Payenia flat-slab period.

Provenance studies of coastal facies sediments associated with the uplift of the Andes (Rodríguez et al. 2012) and the Neuquén Basin (Tunik \& Lazo 2008; Tunik et al. 2010; Di Giulio et al. 2012) shed light on the sediment sources necessary for palaeogeographic reconstructions. Within that framework, Naipauer et al. (2014) present an important contribution to the understanding of the tectonic and sedimentary history of a main Andean basin through a 


\section{INTRODUCTION}

combination of field data, petrography and provenance characteristics of detrital zircons from a Kimmeridgian lowstand wedge within the Tordillo Formation from the Neuquén Basin (Fig. 1), westcentral Argentina. They present new U-Pb detrital zircon ages indicating that the most important source region of sediment supply to the basin was the Jurassic Andean magmatic arc, which has significant implications for the provenance and absolute age of the Jurassic-Cretaceous boundary in the Neuquén Basin.

\section{Quaternary tectonics and geohazards}

The Andes of central Chile and Argentina is one of the most hazardous seismic zones of South America (Holtkamp et al. 2011). The strongest earthquake ever recorded occurred just south of the study area in 1960 (Valdivia, $M_{\mathrm{w}}$ 9.5), and was associated with the plate boundary to seismicity. The February 2010 Maule earthquake $\left(M_{\mathrm{w}} 8.8\right)$ occurred in this region, and generated a tsunami as well as shallow landslides, liquefaction and ground rupture (DICUChile 2012). While high-magnitude inter-plate earthquakes predominate in the Pacific coast, intraplate seismicity related to active Quaternary faults is characteristic of the Andean Main Range and foreland areas (e.g. Barrientos et al. 2004; Alvarado et al. 2005, 2007; Ahumada \& Costa 2009; Farías et al. 2010). For instance, new findings reveal that the San Ramon Fault, which crosses the eastern urban area of Santiago, Chile is capable of generating earthquakes of up to $M_{\mathrm{w}} c .7 .5$ (Vargas et al. 2014). Additional sources of seismicity are mediumdepth intra-plate earthquakes that mainly affect the Chilean central valley area, the Chilean coastal area and Andes Principal Cordillera (Leyton et al. 2010).

The present active orogenic front is located in the piedmont of central-western Argentina (Cortés et al. 1999; Costa et al. 2000a). This area shows intense neotectonic activity evidenced by Quaternary faulting and seismic activity (Costa et al. 2000a, b; Siame et al. 2006), corresponding to shallow intraplate earthquakes at depths of $<30 \mathrm{~km}$. This active orogenic front is composed of a series of east- and west-verging reverse faults with geomorphological evidence of Quaternary displacements (Moreiras et al. 2014). According to geometry of these active faults, the probable maximum earthquake magnitudes range from $M_{\mathrm{w}} 5.4$ to 6.8 , depending on the fault (Moreiras et al. 2014).

The contribution by Cortés et al. (2014) presents a synoptic overview of Quaternary structures across the Precordillera and the low foothills south of the Precordillera. They document the growing lateral expansion of deformation and the subsequent creation of topographic highs and depressions, with a particular emphasis on the Uspallata-Calingasta Valley. They attribute this deformation to preexisting structural elements of the Triassic Cuyo Basin.

At the other end of the Barreal-Las Peñas deformation zone, Costa et al. (2014) analysed the Quaternary shortening of the orogenic front of the Central Andes of Argentina $\left(32^{\circ} 15^{\prime}-32^{\circ} 40^{\prime} \mathrm{S}\right)$. The 40 km NNW-trending Las Peñas Thrust System, one of the key structures along the Andean orogenic front, is described in detail. They suggest the Las Peñas Thrust System represents the latest stage of the eastwards migration of an imbricated fan structure, responsible for the neotectonic uplift of the Las Peñas-Las Higueras range in the Southern Precordillera.

Zárate et al. (2014) recognized fluvio-aeolian deposits fractured and folded by faulting together with some landforms of volcanic origin between 33 and $34^{\circ} \mathrm{S}$. Alluvial fans, related to several Quaternary aggradational cycles, are the most remarkable geomorphological units described in this study. Several tectonic features are present and give rise to conspicuous morphological features. Some streams are structurally controlled by faults, while several drainage anomalies indicate active tectonic processes. Although precise data are still needed, several episodes of Pleistocene-present-day erosion are identified.

García \& Casa (2014) combine field and subsurface data in an analysis of neotectonic structures in the Andean foothills between 33 and $34^{\circ} \mathrm{S}$ latitude. They demonstrate a decrease in neotectonic deformation and seismicity south of the flat-slab transition and estimate Quaternary rock uplift rates. Based on the estimated uplift rates and fault lengths, the authors infer that earthquakes with $M_{\mathrm{w}}$ of 6.4-7.25 are responsible for generating the larger faults present with their study area.

There is a necessity for a comprehensive regional catalogue of historical earthquakes and their environmental ground effects, such as liquefaction, ground cracking or landslides, in central Chile and Argentina. Specific palaeo-seismological studies are uncommon, and historic observations in remote mountain areas are extremely rare. Nevertheless, a catalogue of environmental effects is fundamental to understanding and quantifying the degree of hazard and vulnerability of this region. Moreiras \& Páez (2014) provide a comprehensive review of historic destructive shallow crustal earthquakes in central-western Argentina and their related hazards associated to both shaking and environment effects such as liquefaction and landslides. They discuss the shortcomings of seismic hazard assessments, particularly for potential earthquakes related to blind faults, in a region of increasing population. 

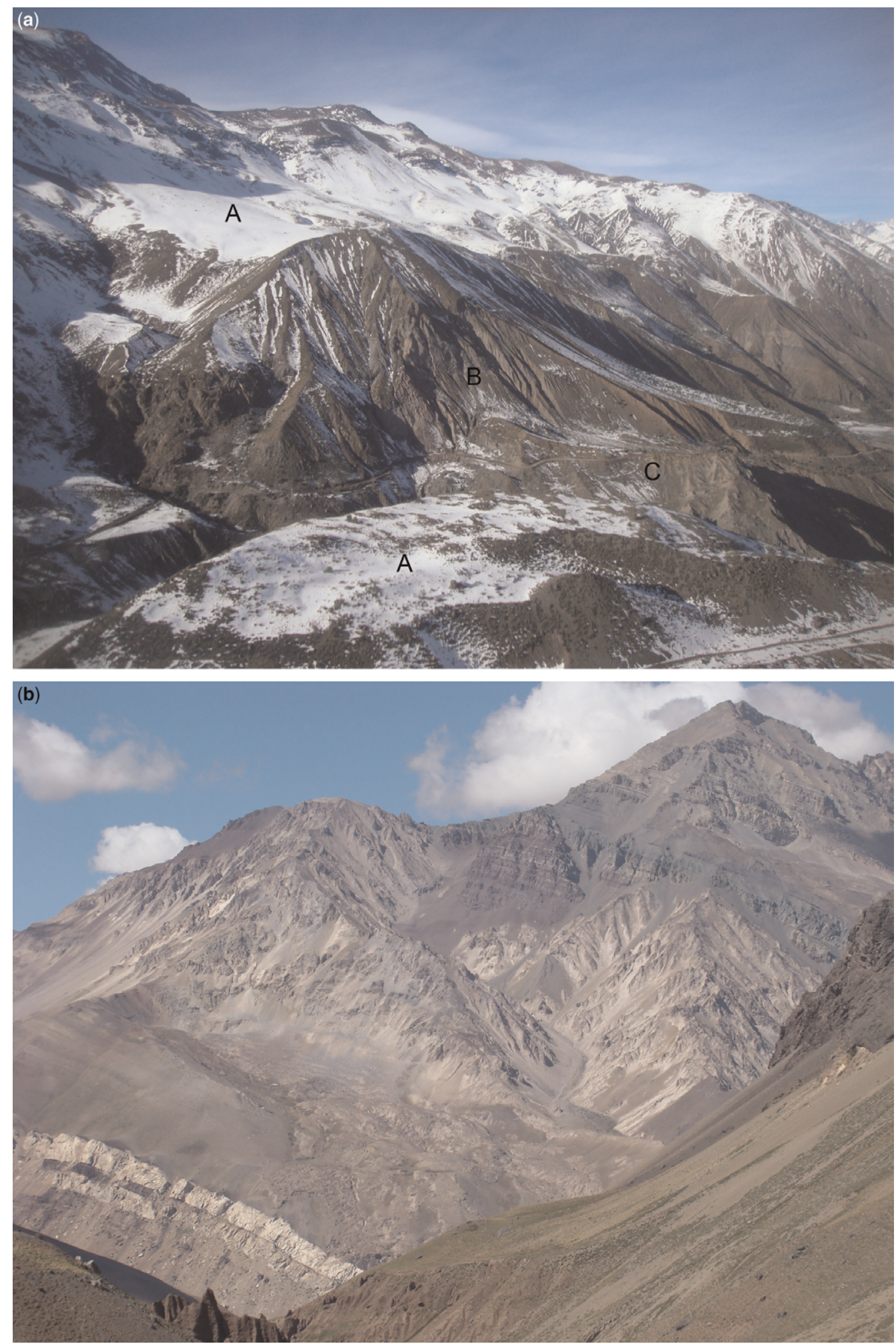


\section{INTRODUCTION}

Landslides inventory maps have been compiled at different scales. In Argentina, the Mendoza river valley (Moreiras 2004, 2005, 2009a) has been studied extensively, with many deposits which were initially interpreted as glacial in origin reinterpreted as large rock avalanches (Moreiras et al. 2008). Quaternary faults have been proposed to trigger many of the rock avalanches (Moreiras 2006, 2009b). In Chile, Antinao \& Gosse (2009) prepared a large landslide inventory and suggested a relationship with regional faults and seismicity, yet only one historic earthquake in $1958\left(M_{\mathrm{w}} 6.3\right.$, Alvarado et al. 2009) triggered landslides and these were only of medium to large size (volume of a few millions of cubic metres; Sepúlveda et al. 2008). In this context, a major question is whether huge palaeo-landslide deposits observed throughout the Andean region are linked to seismic activity or climatic events, that is, whether these deposits can be used as unambiguous indicators of tectonic or climatic forcing.

Mega-landslides $\left(>10^{6} \mathrm{~m}^{3}\right)$ are a common geomorphic feature of the Central Andes in Chile and Argentina $\left(32-34^{\circ} \mathrm{S}\right)$. Different types and volumes of landslides are usually present in the uplands, located mainly in glacial valleys (Fig. 3). Moreiras \& Sepúlveda (2014) revise and integrate an inventory of mega palaeo-landslides in this portion of Central Andes and discuss traditional hypotheses used to explaining landslide occurrences in the Central Andes. Whereas earthquakes have been widely viewed as the main triggering mechanism in Chilean collapses, palaeo-climatic conditions are considered as the main cause of mega-landslides in Argentina. The authors identify the necessity of future multidisciplinary, specific studies focused on resolving the controversy between seismic- or climate-landslide-triggering mechanism in the Central Andes.

Hermanns et al. (2014) determine the origin and ages of mass movements in the Aconcagua mountain region, Argentina. Deposits previously interpreted as glacial drifts (Penitentes, Horcones and Almacenes) along the Las Cuevas-Horcones valleys are reinterpreted as giant landslides based on morphological, sedimentological and mineralogical studies. A combination of ${ }^{36} \mathrm{Cl}$ terrestrial cosmogenic nuclide $(\mathrm{TCN})$ and $\mathrm{U}$-series dating indicates late Pleistocene-early Holocene ages for these deposits. These new findings suggest that hillslope collapse could be more important than glaciation in the landscape evolution of the central Andes, which is still poorly understood.

\section{External geodynamics and landscape evolution}

The study of the magnitude and timing of surface uplift and its erosional response and relief growth, in conjunction with structural geology and shallow seismicity studies, has been carried out in the Chilean flank of the study region (e.g. Farías et al. 2008). Such studies have determined that the main stage of uplift occurred during late Miocene time and that the river incision in response to uplift was very slow, taking more than 5 million years to arrive at the present-day Pacific-Atlantic watershed. This implies that exhumation is not co-eval to uplift, but it is delayed because of lithological resistance to erosion and climatic settings. The restricted amount of exhumation allows the preservation of geomorphical markers of uplift and erosion, which permit the quantification of this kind of processes. The $2 \mathrm{~km}$ magnitude of surface uplift deduced by Farías et al. (2008) at $c .34^{\circ} \mathrm{S}$ on the western flanks of the Andes has been confirmed by a recent stable isotope palaeo-altimetry study on the eastern flanks of the range (Hoke et al. 2014a). The linkage between climate and tectonics in the Andes remains unresolved. Some research suggests that the development of relief on the western flank of the Andes may be linked with the amount of shortening and precipitation rates (e.g. Farías et al. 2012), while other studies (Carretier et al. 2013, 2014) demonstrate that precipitation is negatively correlated with millennial-scale erosion rates.

Hoke et $\boldsymbol{a l}$. (2014b) present new apatite (UTh)/He thermochronology data and a geomorphic analysis of two large rivers from the Frontal Cordillera of Argentina that bear on the timing and origin of mountain uplift. Their data demonstrate that the Frontal Cordillera was never buried by a thick package of foreland basin sediments, as is commonly assumed; rather, there was always a positive or near-surface topographic feature since at least Miocene time. These findings constitute a new view on the evolution of the proximal parts of the Andean foreland, demonstrating that sediment deposition was restricted to relatively small, deep intermontane basins between the rising ranges and not a continuous foreland. Moreover, this contribution provides evidence that uplift of the Frontal Cordillera occurred during late Miocene time, when exhumation rates increased. These results are important for investigators working in a variety of different fields in the geosciences, specifically those studying

Fig. 3. (a) Cortaderas mega-landslide (A: Holocene) in the Yeso valley, Chile, reactivated during the 1958 Las Melosas shallow crustal earthquake (B: scarp, C: deposit). (b) the Blanca rock avalanche in Mendoza river basin, Argentina. The deposit running along the Blanca gully reached the valley damming the Cuevas River during late Pleistocene time. 


\section{S. A. SEPÚLVEDA ET AL.}

Andean orogenesis and the role of tectonics and climate.

Carretier et al. (2014) analyse the relationship between erosion and tectonic, climatic and geomorphical controls $\left(c .27^{\circ} \mathrm{S}\right.$ and $\left.39^{\circ} \mathrm{S}\right)$. The catchmentmean decadal and millennial erosion rates for central Chile and two sites of Argentina are studied with respect to the long-term evolution of the topography over millions of years. In this paper, they discuss why decadal and millennial erosion rates are negatively correlated with mean runoff south of $32^{\circ} \mathrm{S}$ (Pepin et al. 2010; Carretier et al. 2013) and explore the correlation of these parameters with vegetation, runoff, lithology and topography. In addition, the north-south pattern of erosion rates with cumulative erosion estimates is contrasted with structural and thermochronological data. They consider new data from the Bio-Bío catchment and previously published catchment-mean decadal and millennial erosion rates (Pepin et al. 2010, 2013; Aguilar et al. 2013; Carretier et al. 2013).

Interplay between tectonic and erosional processes is also brought to the forefront by Rodríguez et al. (2014). They combine geomorphological analysis of palaeo-surfaces and $\mathrm{U}-\mathrm{Pb}$ zircon geochronology of overlying tuffs to reconstruct the Neogene landscape evolution of north-central Chile $\left(28-32^{\circ} \mathrm{S}\right)$. At this latitude, the authors demonstrate the presence of three major uplift stages: (1) eastern Coastal Cordillera and the Frontal Cordillera during early-middle? Miocene time; (2) the Coastal Cordillera during late Miocene time; and (3) uplift of a Pleistocene pediplain post-500 ka. These stages correlate with episodes of increased deformation throughout the Central Andes, starting after a late Oligocene-early Miocene episode of increased plate convergence.

\section{Concluding remarks}

The landscape of convergent margins is the result of the complex interplay between internal tectonic processes, surface deformation and erosive processes driven by the interactions of tectonics and climate. The Andes of central Chile and Argentina, where a drastic change in the subduction angles and precipitation gradients occur, is a key locality for the study of such interactions between internal and external geodynamic processes.

This Special Publication aims to improve our understanding of tectonic and landscape evolution of the Andean range at different timescales, as well as the mutual relationship between internal and external mechanisms in Cenozoic deformation, mountain building, topographic evolution, basin development and mega-landslides across the flat slab to normal subduction segments. The geodynamic processes of the Andes of central Chile and Argentina are analysed within a number of subdisciplines of the Earth Sciences including tectonics, petrology, geophysics, geochemistry, structural geology, geomorphology, engineering geology, stratigraphy and sedimentology.

This book is the result of collaborative work supported by Unesco IGCP project 586-Y. In addition, the editors received support from projects FONDECYT 11085022, 1120272 (M. Farías), 1090165 (L. Pinto), NSF award OISE-0601957, ACS-PRF Grant 52480-DNI8 (G. Hoke) and PIP 638 y PICT 1079 (L. Giambiagi).

\section{References}

Aguilar, G., Riquelme, R., Martinod, J. \& Darrozes, J. 2013. Rol del clima y la tectónica en la evolución geomorfológica de los Andes Semiáridos chilenos entre los $27-32^{\circ} \mathrm{S}$. Andean Geology, 40, 79-101.

Ahumada, E. A. \& Costa, C. H. 2009. Deformación cuaternaria en la culminación norte del corrimiento las Peñas, frente orogénico andino, Precordillera Argentina. XII Congreso Geológico Chileno, Santiago, Chile.

Allmendinger, R. W., Isacks, B. L., Jordan, T. E. \& KAY, S. M. 1997. The evolution of the Altiplano-Puna plateau of the Central Andes. Annual Reviews of Earth Science, 25, 139-174.

Alvarado, P., Beck, S., Zandt, G., Araujo, M. \& Triep, E. 2005. Crustal deformation in the south-central Andes backarc terranes as viewed from regional broadband seismic waveform modelling. Geophysical Journal International, 163, 580-598, http://dx.doi.org/ 10.1111/j.1365-246X.2005.02759.x

Alvarado, P., Beck, S. \& Zandt, G. 2007. Crustal structure of the south-central Andes Cordillera and backarc region from regional waveform modelling. Geophysical Journal International, 170, 858-875, http://dx. doi.org/10.1111/j.1365-246X.2007.03452.X

Alvarado, P., Barrientos, S., Saez, M., Astroza, M. \& BECK, S. 2009. Source study and tectonic implications of the historic 1958 Las Melosas crustal earthquake, Chile, compared to earthquake damage. Physics of the Earth and Planetary Interiors, 175, 26-36.

Alvarez, O., Gimenez, M. E., Martinez, M. P., LinceKLinger, F. \& BraitenberG, C. 2014. New insights into the Andean crustal structure between $32^{\circ}$ and $34^{\circ} \mathrm{S}$ from GOCE satellite gravity data and EGM2008 model. In: Sepúlveda, S. A., Giambiagi, L. B., Moreiras, S. M., Pinto, L., Tunik, M., Hoke, G. D. \& Farías, M. (eds) Geodynamic Processes in the Andes of Central Chile and Argentina. Geological Society, London, Special Publications, 399. First published online February 6, 2014, http://dx.doi.org/10.1144/ SP399.3

Antinao, J. L. \& Gosse, J. 2009. Large rockslides in the Southern Central Andes of Chile $\left(32-34.5^{\circ} \mathrm{S}\right)$ : tectonic control and significance for Quaternary landscape evolution. Geomorphology, 104, 117-133.

Barrientos, S., Vera, E., Alvarado, P. \& Monfret, T. 2004. Crustal seismicity in central Chile. Journal of South American Earth Sciences, 16, 759-768. 


\section{INTRODUCTION}

Beaumont, C., Jamieson, R. A., Nguyen, M. H. \& MedVEDEv, S. 2004. Crustal channel flows: 1. numerical models with applications to the tectonics of the Himalayan-Tibetan orogeny. Journal of Geophysical Research, 109, B06406, http://dx.doi.org/10.1029/ 2003JB002809

CAHILl, T. \& IsACKS, B. L. 1992. Seismicity and shape of the subducted Nazca Plate. Journal of Geophysical Research: Solid Earth, 97, 17503-17529, http://dx. doi.org/10.1029/92jb00493

Carretier, S., Regard, V. et aL. 2013. Slope and climate variability control of erosion in the Andes of central Chile. Geology, 41, 195-198, http://dx.doi.org/10. $1130 / \mathrm{g} 33735.1$

Carretier, S., Tolorza, V. et AL. 2014. Erosion in the Chilean Andes between $27^{\circ} \mathrm{S}$ and $39^{\circ} \mathrm{S}$ : tectonic, climatic and geomorphic control. In: SEPúlvedA, S. A., Giambiagi, L. B., Moreiras, S. M., Pinto, L., Tunik, M., Hoke, G. D. \& Farías, M. (eds) Geodynamic Processes in the Andes of Central Chile and Argentina. Geological Society, London, Special Publications, 399. First published online April 9, 2014, http://dx.doi.org/10.1144/SP399.16

Charrier, R., BAEZA, O. ET AL. 2002. Evidence for Cenozoic extensional basin development and tectonic inversion south of the flat-slab segment, southern Central Andes, Chile $\left(33^{\circ}-36^{\circ}\right.$ S.L. $)$. Journal of South American Earth Sciences, 15, 117-139.

Charrier, R., Ramos, V. A., Tapia, F. \& Sagripanti, L. 2014. Tectono-stratigraphic evolution of the Andean Orogen between 31 and $37^{\circ} \mathrm{S}$ (Chile and Western Argentina). In: Sepúlveda, S. A., Giambiagi, L. B., Moreiras, S. M., Pinto, L., Trnik, M., Hoke, G. D. \& FARÍAs, M. (eds) Geodynamic Processes in the Andes of Central Chile and Argentina. Geological Society, London, Special Publications, 399. First published online August 27, 2014, http://dx.doi.org/10. 1144/SP399.20

Cortés, J. M., Vinciguerra, P., Yamín, M. \& Pasini, M. M. 1999. Tectónica cuaternaria de la Región Andina del Nuevo Cuyo $\left(28^{\circ}-38^{\circ}\right.$ LS). In: Geología Argentina, Servicio Geológico Minero Argentino, Subsecretaría de Minería, Buenos Aires.

Cortés, J. M., Terrizzano, C. M., Pasini, M. M., Yamin, M. G. \& CASA, A. L. 2014. Quaternary tectonics along oblique deformation zones in the Central Andean retrowedge between $31^{\circ} 30^{\prime} \mathrm{S}$ and $35^{\circ} \mathrm{S}$. In: SEPúlvedA, S. A., Giambiagi, L. B., Moreiras, S. M., Pinto, L., Tunik, M., Hoke, G. D. \& Farías, M. (eds) Geodynamic Processes in the Andes of Central Chile and Argentina. Geological Society, London, Special Publications, 399. First published online February 5, 2014, http://dx.doi.org/10.1144/SP399.10

Costa, C. H., Machette, M. N. et AL. 2000a. Map and Database of Quaternary Faults and Folds in Argentina. USGS Open-File Report 00-0108.

Costa, C. H., Gardini, C. E., Diederix, H. \& Cortés, J. M. 2000b. The Andean orogenic front at Sierra de Las Peñas-Las Higueras, Mendoza, Argentina. Journal of South American Earth Sciences, 13, 287-292.

Costa, C. H., Ahumada, E. A., Gardini, C. E., Vázquez, F. R. \& Diederix, H. 2014. Quaternary shortening at the orogenic front of the Central Andes of Argentina: the Las Peñas Thrust System. In: Sepúlveda, S. A.,
Giambiagi, L. B., Moreiras, S. M., Pinto, L., TuniK, M., Hoke, G. D. \& Farías, M. (eds) Geodynamic Processes in the Andes of Central Chile and Argentina. Geological Society, London, Special Publications, 399. First published online February 6, 2014, http://dx.doi.org/10.1144/SP399.5

Di Giulio, A., Ronchi, A., Sanfilippo, A., Tiepolo, M., Pimentel, M. \& Ramos, V. A. 2012. Detrital zircon provenance from the Neuquén Basin (south-central Andes): Cretaceous geodynamic evolution and sedimentary response in a retroarc-foreland basin. Geology, 40, 559-562.

DIC-UChILe 2012. Mw $=8.8$ Terremoto en Chile, $27 \mathrm{de}$ febrero 2010. Moroni, M. O., Casares, A. (eds) Departamento de Ingeniería Civil, Facultad de Ciencias Físicas y Matemáticas Universidad de Chile.

Farías, M., Charrier, R. et AL. 2008. Late Miocene high and rapid surface uplift and its erosional response in the Andes of central Chile (33 degrees-35 degrees S). Tectonics, 27, http://dx.doi.org/10.1029/2006tc 002046

FARÍAs, M., ComTe, D. ET AL. 2010. Crustal-scale structural architecture in central Chile based on seismicity and surface geology: Implications for Andean mountain building. Tectonics, 29, http://dx.doi.org/10. 1029/2009tc002480

Farías, M., Charrier, R. ET AL. 2012. Contribución de largo-plazo de la segmentación climática en Chile central a la construcción Andina. XIII Congreso Geológico Chileno, Antofagasta, 194-196.

García, V. H. \& CASA, A. L. 2014. Quaternary tectonics and seismic potential of the Andean retrowedge at 33-34 S. In: Sepúlveda, S. A., Giambiagi, L. B., Moreiras, S. M., Pinto, L., Tunik, M., Hoke, G. D. \& FARÍAs, M. (eds) Geodynamic Processes in the Andes of Central Chile and Argentina. Geological Society, London, Special Publications, 399. First published online February 27, 2014, http://dx.doi.org/10. 1144/SP399.11

Giambiagi, L., Mescua, J., Bechis, F., Martinez, A. \& Folguera, A. 2011. Pre-Andean deformation of the Precordillera southern sector, southern Central Andes. Geosphere, 7, 219-239, http://dx.doi.org/10.1130/ ges00572.1

Giambiagi, L., Mescua, J. et AL. 2014a. Reactivation of Paleozoic structures during Cenozoic deformation in the Cordón del Plata and Southern Precordillera ranges (Mendoza, Argentina). Journal of Iberian Geology, 40, 309-320.

Giambiagi, L., Tassara, A. ET AL. 2014b. Evolution of shallow and deep structures along the MaipoTunuyán transect $\left(33^{\circ} 40^{\prime} \mathrm{S}\right)$ : from the Pacific coast to the Andean foreland. In: Sepúlveda, S. A., Giambiagi, L. B., Moreiras, S. M., Pinto, L., Tunik, M., Hoke, G. D. \& Farías, M. (eds) Geodynamic Processes in the Andes of Central Chile and Argentina. Geological Society, London, Special Publications, 399. First published online February 27,2014 , http:// dx.doi.org/10.1144/SP399.14

Godoy, E. 2014. The north-western margin of the Neuquén Basin in the headwater region of the Maipo drainage, Chile. In: Sepúlveda, S. A., Giambiagi, L. B., Moreiras, S. M., Pinto, L., Tunik, M., HoKe, G. D. \& Farías, M. (eds) Geodynamic Processes in the Andes of Central Chile and Argentina. 


\section{S. A. SEPÚLVEDA ET AL.}

Geological Society, London, Special Publications, 399. First published online February 27,2014 , http:// dx.doi.org/10.1144/SP399.13

Heredia, N., Farias, P., Garcia-Sansegundo, J. \& Giambiagi, L. 2012. The basement of the Andean Frontal Cordillera in the Cordon del Plata (Mendoza, Argentina): geodynamic evolution. Andean Geology, 39, 242-257, http://dx.doi.org/10.5027/andgeo V39n2-a03

Hermanns, R. L., Fauqué, L. \& Wilson, C. G. J. 2014. ${ }^{36} \mathrm{Cl}$ terrestrial cosmogenic nuclide dating suggests late Pleistocene to Early Holocene mass movements on the south face of Aconcagua mountain and in the Las Cuevas-Horcones valleys, Central Andes, Argentina. In: Sepúlveda, S. A., Giambiagi, L. B., Moreiras, S. M., Pinto, L., Tunik, M., Hoke, G. D. \& FARÍAs, M. (eds) Geodynamic Processes in the Andes of Central Chile and Argentina. Geological Society, London, Special Publications, 399. First published online May 23, 2014, updated June 13, 2014, http:// dx.doi.org/10.1144/SP399.19

Hoke, G. D., Giambiagi, L. B., Garzione, C. N., Mahoney, J. B. \& Strecker, M. R. 2014a. Neogene Paleoelevation of intermontane basins in a narrow, compressional mountain range. Earth and Planetary Science Letters, 406, 153-164, http://dx.doi.org/10. 1016/j.epsl.2014.08.032

Hoke, G. D., Graber, N. R., Mescua, J. F., Giambiagi, L. B., Fitzgerald, P. G. \& Metcalf, J. R. $2014 b$. Near pure surface uplift of the Argentine Frontal Cordillera: insights from (U-Th)/He thermochronometry and geomorphic analysis. In: Sepúlveda, S. A., Giambiagi, L. B., Moreiras, S. M., Pinto, L., Tunik, M., Hoke, G. D. \& Farías, M. (eds) Geodynamic Processes in the Andes of Central Chile and Argentina. Geological Society, London, Special Publications, 399. First published online February 5, 2014, http:// dx.doi.org/10.1144/SP399.4

Holtkamp, S. G., Pritchard, M. E. \& Lohman, R. B. 2011. Earthquake swarms in South America. Geophysical Journal International, 187, 128-146.

IsACKs, B. 1988. Uplift of the Central Andean plateau and bending of the Bolivian Orocline. Journal of Geophysical Research, 93, 3211-3231.

Jara, P., Likerman, J., Winocur, D., Ghiglione, M. C., Cristallini, E. O., Pinto, L. \& Charrier, R. 2014 Role of basin width variation in tectonic inversion: insight from analogue modelling and implications for the tectonic inversion of the Abanico Basin, $32^{\circ}-$ $34^{\circ} \mathrm{S}$, Central Andes. In: Sepúlveda, S. A., Giambiagi, L. B., Moreiras, S. M., Pinto, L., Tunik, M., HoKe, G. D. \& Farías, M. (eds) Geodynamic Processes in the Andes of Central Chile and Argentina. Geological Society, London, Special Publications, 399. First published online February 27, 2014, http:// dx.doi.org/10.1144/SP399.7

Jordan, T. E., Isacks, B. L., Allmendinger, R. W., Brewer, J. A., Ramos, V. A. \& Ando, C. J. 1983. Andean tectonics related to geometry of subducted Nazca plate. Geological Society of America Bulletin, 94, 341-361.

Leyton, F., Ruiz, S. \& Sepúlveda, S. A. 2010. Reevaluación del peligro sísmico probabilístico en Chile central. Andean Geology, 37, 455-472.
Molnar, P. \& Lyon-Caen, H. 1988. Some simple physical aspects of the support, structure and evolution of mountain belts. In: Clark, S. P., JR., Burchfiel, B. C. \& Suppe, J. (eds) Processes in Continental Lithospheric Deformation. GSA Special Paper, Boulder, CO, 281, 179-208, http://dx.doi.org/10. 1130/SPE218-p179

Moreiras, S. M. 2004. Zonificación de peligrosidad y de riesgo de procesos de remoción en masa en el valle del río Mendoza. Provincia de Mendoza. PhD thesis, Universidad Nacional de San juan.

Moreiras, S. M. 2005. Climatic effect of ENSO associated with landslide occurrence in the Central Andes, Mendoza province, Argentina. Landslides, 2, 53-59.

Moreiras, S. M. 2006. Frequency of debris flows and rockfall along the Mendoza river valley (Central Andes), Argentina. Special Issue Holocene Environmental Catastrophes in South America. Quaternary International, 158, 110-121.

Moreiras, S. M. 2009a. Análisis estadístico probabilístico de las variables que condicionan la inestabilidad de las laderas en los valles de los ríos Las Cuevas y Mendoza. Revista de la Asociación Geológica, $\mathbf{6 5}$, $321-327$.

Moreiras, S. M. 2009b. Clustering of Pleistocene rock avalanches in the Central Andes, Argentina. In: Salfity, J. A. \& Marquillas, R. A. (eds) Cenozoic Geology of Central Andes of Argentina. SCS Publisher, Salta, 265-282.

Moreiras, S. M. \& PÁez, M. S. 2014. Historical damage and earthquake environmental effects related to shallow intraplate seismicity of central western Argentina. In: Sepúlveda, S. A., Giambiagi, L. B., Moreiras, S. M., Pinto, L., Tunik, M., Hoke, G. D. \& FARÍAs, M. (eds) Geodynamic Processes in the Andes of Central Chile and Argentina. Geological Society, London, Special Publications, 399. First published online February 19, 2014, http://dx.doi.org/10. $1144 /$ SP399.6

Moreiras, S. M. \& Sepúlveda, S. A. 2014. Megalandslides in the Andes of central Chile and Argentina $\left(32^{\circ}-34^{\circ} \mathrm{S}\right)$ and potential hazards. In: Sepúlveda, S. A., Giambiagi, L. B., Moreiras, S. M., Pinto, L., Tunik, M., Hoke, G. D. \& Farías, M. (eds) Geodynamic Processes in the Andes of Central Chile and Argentina. Geological Society, London, Special Publications, 399. First published online May 13, 2014, http://dx.doi.org/10.1144/ SP399.18

Moreiras, S. M., Lenzano, M. G. \& Riveros, N. 2008. Inventario de procesos de remoción en masa en el Parque provincial Aconcagua, provincia de Mendoza Argentina. Multiequina. Latin American Journal of Natural Resources, 17, 129-146.

Moreiras, S. M., Giambiagi, L. B., Spagnotto, S., Nacif, S., Mescua, J. F. \& Toural, R. 2014. Caracterización de fuentes sismogénicas en el frente orogénico activo de los Andes Centrales a la latitud de la ciudad de Mendoza $\left(32^{\circ} 50^{\prime}-33^{\circ} \mathrm{S}\right)$. Andean Geology, 41, 345-361.

Mpodozis, C. \& Cornejo, P. 2012. Cenozoic tectonics and porphyry copper systems of the chilean andes. Society of Economic Geologists, Special Publication, 16, 329-360. 


\section{INTRODUCTION}

Mrodozis, C. \& Ramos, V. A. 1989. The Andes of Chile and Argentina. In: Ericksen, G. E., CAÑAs, M. T. \& Reinemud, J. A. (eds) Geology of the Andes and its relation to Hydrocarbon and Mineral Resources. Circum-Pacific Council for Energy and Mineral Resources, Houston, Texas, 59-90.

Muñoz-SÁez, C., Pinto, L., Charrier, R. \& Nalpas, T. 2014. Influence of depositional load on the development of a shortcut fault system during the inversion of an extensional basin: the Eocene-Oligocene Abanico Basin case, central Chile Andes $\left(33^{\circ}-35^{\circ} \mathrm{S}\right)$. Andean Geology, 41, 1-28.

Naipauer, M., Tunik, M., Marques, J. C., Rojas Vera, E. A., Vujovich, G. I., Pimentel, M. M. \& Ramos, V. A. 2014. U-Pb detrital zircon ages of Upper Jurassic continental successions: implications for the provenance and absolute age of the Jurassic-Cretaceous boundary in the Neuquén Basin. In: Sepúlveda, S. A., Giambiagi, L. B., Moreiras, S. M., Pinto, L., TuniK, M., Hoke, G. D. \& Farías, M. (eds) Geodynamic Processes in the Andes of Central Chile and Argentina. Geological Society, London, Special Publications, 399. First published online March 4, 2014, http://dx.doi.org/10.1144/SP399.1

Pepin, E., Carretier, S., Guyot, J. \& Escobar, F. 2010. Specific suspended sediment yields of the Andean rivers of Chile and their relationship to climate, slope and vegetation. Hydrological Sciences Journal, 55, 1190-1205.

Pepin, E., Carretier, S. et al. 2013. Pleistocene landscape entrenchment: a geomorphological mountain to foreland field case, the Las Tunas system, Argentina. Basin Research, 25, 613-637, http://dx.doi.org/10. 1111/bre. 12019

Ramos, V. 1988. The tectonics of the Central Andes: $30^{\circ}-33^{\circ} \mathrm{S}$ latitude. In: Clark, S. \& Burchfiel, D. (eds) Processes in Continental Lithospheric Deformation. Geological Society of America, Boulder, Special Paper, 218, 31-54, http://dx.doi.org/10.1130/ SPE218-p31

Ramos, V. A., Cegarra, M. \& Cristallini, E. 1996. Cenozoic tectonics of the High Andes of west-central Argentina (30-36 $\mathrm{S}$ latitude). Tectonophysics, 259. $185-200$

Rodríguez, M. P., Pinto, L. \& Encinas, A. 2012. Cenozoic erosion in the Andean forearc in Central Chile $\left(33^{\circ}-34^{\circ} \mathrm{S}\right)$ : sediment provenance inferred by heavy mineral studies. In: Rasbury, T. E., Hemming, S. R. \& RigGs, N. R. (eds) Mineralogical and Geochemical Approaches to Provenance. Geological Society of America, Special Papers, 487, 141-162, http://dx. doi.org/10.1130/2012.2487(09)

Rodríguez, M. P., Aguilar, G., Urresty, C. \& CharRIER, R. 2014. Neogene landscape evolution in the Andes of north-central Chile between 28 and $32^{\circ} \mathrm{S}$ : interplay between tectonic and erosional processes. In: Sepúlveda, S. A., Giambiagi, L. B., Moreiras, S. M., Pinto, L., Tunik, M., Hoke, G. D. \& Farías, M. (eds) Geodynamic Processes in the Andes of Central Chile and Argentina. Geological Society, London, Special Publications, 399. First published online April 4, 2014, http://dx.doi.org/10.1144/SP399.15

Sagripanti, L., Aguirre-Urreta, B., Folguera, A. \& Ramos, V. A. 2014. The Neocomian of Chachahuén
(Mendoza, Argentina): evidence of a broken foreland associated with the Payenia flat-slab. In: SEPúLvedA, S. A., Giambiagi, L. B., Moreiras, S. M., Pinto, L., Tunik, M., Hoke, G. D. \& Farías, M. (eds) Geodynamic Processes in the Andes of Central Chile and Argentina. Geological Society, London, Special Publications, 399. First published online February 5, 2014 , http://dx.doi.org/10.1144/SP399.9

Sánchez, M., Lince Klinger, F., Martinez, M. P., Alvarez, O., Ruiz, F., Weidmann, C. \& Folguera, A. 2014. Geophysical characterization of the upper crust in the transitional zone between the Pampean flat slab and the normal subduction segment to the south $\left(32-34^{\circ} \mathrm{S}\right)$ : Andes of the Frontal Cordillera to the Sierras Pampeanas. In: Sepúlveda, S. A., GiamBiagi, L. B., Moreiras, S. M., Pinto, L., Tunik, M., Hoke, G. D. \& Farías, M. (eds) Geodynamic Processes in the Andes of Central Chile and Argentina. Geological Society, London, Special Publications, 399. First published online February 6, 2014, http:// dx.doi.org/10.1144/SP399.12

Sepúlveda, S. A., Astroza, M., Kausel, E., Campos, J., Casas, E. A., Rebolledo, S. \& Verdugo, R. 2008. New findings on the 1958 Las Melosas earthquake sequence, Central Chile: implications for Seismic Hazard related to shallow crustal earthquakes in subduction zones. Journal of Earthquake Engineering, 12, 432-455, http://dx.doi.org/10.1080/13632460 701512951

SHeFFeLs, B. 1990. Lower bound on the amount of crustal shortening in the Central Bolivian Andes. Geology, 18, $812-815$.

Siame, L., Bellier, O. \& Sebrier, M. 2006. Active tectonics in the Argentine Precordillera and western Sierras Pampeanas. Revista de la Asociación Geológica Argentina, 61, 604-619.

Suriano, J., Limarino, C. O., Tedesco, A. M. \& Alonso, M. S. 2014. Sedimentation model of piggyback basins: Cenozoic examples of San Juan Precordillera, Argentina. In: Sepúlveda, S. A., Giambiagi, L. B., Moreiras, S. M., Pinto, L., TuniK, M., Hoke, G. D. \& FARÍAs, M. (eds) Geodynamic Processes in the Andes of Central Chile and Argentina. Geological Society, London, Special Publications, 399. First published online February 28, 2014, http://dx.doi.org/10.1144/ SP399.17

TuniK, M. \& LAzo, D. 2008. Microfacies, fósiles y paleoambientes de la Formación Agrio en el sector centro-norte de Neuquén. Actas XII Reunión Argentina de Sedimentología, Buenos Aires, 177.

Tunik, M. A., Folguera, A., Naipauer, M., Pimentel, M. \& Ramos, V. A. 2010. Early uplift and orogenic deformation in the Neuquén basin: constraints on the Andean uplift from $\mathrm{U}-\mathrm{Pb}$ and $\mathrm{Hf}$ analyses of detrital zircons. Tectonophysics, 489, 258-273.

Vargas, G., Klinger, Y., Rockwell, T. K., Forman, S. L., Rebolledo, S., Baize, S., Lacassin, R. \& ARmiJo, R. 2014. Probing large intraplate earthquakes at the west flank of the Andes. Geology, http://dx.doi. org/10.1130/G35741.1

Whipple, K. \& Meade, B. 2006. Orogen response to changes in climatic and tectonic forcing. Earth and Planetary Science Letters, 243, 218-228, http://dx. doi.org/10.1016/j.epsl.2005.12.022 


\section{S. A. SEPÚLVEDA ET AL.}

Winocur, D. A., LitvaK, V. D. \& Ramos, V. A. 2014. Magmatic and tectonic evolution of the Oligocene Valle del Cura basin, main Andes of Argentina and Chile: evidence for generalized extension. In: SEPúlvedA, S. A., Giambiagi, L. B., Moreiras, S. M., Pinto, L., Tunik, M., Hoke, G. D. \& Farías, M. (eds) Geodynamic Processes in the Andes of Central Chile and Argentina. Geological Society, London, Special Publications, 399. First published online February 17, 2014, http://dx.doi.org/10.1144/ SP399.2
Zárate, M. A., Mehl, A. \& Perucca, L. 2014. Quaternary evolution of the Cordillera Frontal piedmont between $c .33^{\circ}$ and $34^{\circ} \mathrm{S}$ Mendoza, Argentina. In: Sepúlveda, S. A., Giambiagi, L. B., Moreiras, S. M., Pinto, L., Tunik, M., Hoke, G. D. \& Farías, M. (eds) Geodynamic Processes in the Andes of Central Chile and Argentina. Geological Society, London, Special Publications, 399. First published online February 5, 2014, http://dx.doi.org/10.1144/ SP399.8 